\title{
Louis Pierre Gratiolet (1815-1865): The Cerebral Lobes and Fissures
}

\author{
J.M.S. Pearce \\ Emeritus Consultant Neurologist, Department of Neurology, Hull Royal Infirmary, and Hull York Medical School, \\ Hull, UK
}

\section{Key Words}

Comparative anatomy $\cdot$ Cerebral lobes $\cdot$ Optic radiation

\begin{abstract}
Early anatomists referred to parts of the brain as 'posterior' and 'anterior.' But after comparing many primate brains, Gratiolet noticed a pattern of folds or sulci and convolutions marked by fissures of increasing complexity in the more advanced mammalian brains. The primary fissures he could also identify in the smoother ape brains. He was the first to separate four brain lobes (frontal, parietal, temporosphenoidal, occipital) and a fifth central lobe or insula. He demonstrated a sequence of closure of the cranial sutures, and he identified and named the optic radiation. Because he was reluctant to equate brain size with intelligence, Gratiolet was involved in a prolonged polemic with Broca.
\end{abstract}

Copyright $\odot 2006$ S. Karger AG, Basel

As students, we had to learn about Gratiolet's optic radiation. The axons of the lateral geniculate body pass beneath the optic tract and the posterior horn of the lateral ventricle where they join the optic radiation to end in the striate cortex. Who was Gratiolet? Was this eponymous discovery his only contribution to medicine?

\section{KARGER \\ Fax +41613061234 E-Mail karger@karger.ch} www.karger.com
(C) 2006 S. Karger AG, Basel 0014-3022/06/0564-0262\$23.50/0

Accessible online at: www.karger.com/ene
Louis Pierre Gratiolet was born in 1815 at Ste-Foy-LaGrande. Curiously, this was also the home of Pierre Paul Broca. Boulevard Gratiolet now opens into Place Broca as fitting memorials to these founders of the organisation and workings of the brain.

Gratiolet read Medicine in Paris. Under Blainville (1777-1850) he was employed at the Musée de l'Histoire Naturelle in Paris in 1842-1853, where he became a Laboratory assistant. He lectured on anatomy from 1844 to 1850 , and was appointed director of anatomical studies (1853-1862) and deputy to the professor of zoology, Faculty of Science, Paris (1862-1863). Lacking support, he became full professor only late in life (1863) on the death of Isidore Geoffroy Saint-Hilaire. His main researches were devoted to the structure of the brain, but his work was greatly undervalued and he lived in great poverty and hardship. He died in 1865 in Paris.

\section{Definition of Brain Lobes and Fissures}

Gratiolet's major work was in comparative cerebral anatomy where he observed the lobes of the brain and named them by reference to the adjacent skull bones: frontal, parietal, temporal, and occipital lobes. Although the cranial bones were named from the 15th century, 
anatomists referred to cerebral lobes as 'posterior' and 'anterior.' But after comparing many primate brains, Gratiolet noticed a pattern of folds or sulci and convolutions marked by fissures that showed an increasing complexity in the more advanced mammalian brains. Gratiolet also identified the primary fissures in the smoother ape brains. He separated four lobes (frontal, parietal, temporosphenoidal, occipital) and a fifth central lobe, the insula. $\mathrm{He}$ named the parieto-occipital sulcus the 'external perpendicular sulcus'. His main publication was in 1854 [1], summarized in the second volume of Leuret's book [2] in 1857.

According to T.H. Huxley, Gratiolet was the first to state that there is a fundamental difference in the development of the ape brains and that of man. In the apes, the sulci first develop in the posterior parts of the cerebral hemispheres, while, in the human fetus, the sulci first become visible in the frontal lobes.

'Chez tous les singes, les plis postérieurs se développent les premiers; les plis antérieurs se développent plus tard, aussi la vertébre occipitale et la pariétale sont-elles relativement très grandes chez le foetus. L'Homme présente une exception remarquable quant à l'époque de l'apparition des plis frontaux, qui sont les premiers indiqués; mais le développement général du lobe frontal, envisagé seulement par rappor à son volume, suit les mêmes lois que dans les singes' [1].

This notion was based on two examinations intended to differentiate human from primate brain in the mode of their development; one was of a gibbon at term, the other of a 22- to 23-week human fetus. T.H. Huxley disagreed:

'So far as cerebral structure goes, therefore, it is clear that man differs less from the chimpanzee or the orang, than these do even from the monkeys, and that the difference between the brain of the chimpanzee and of man is almost insignificant when compared with that between the chimpanzee brain and that of a lemur' [3].

Though Gratiolet with François Leuret mapped the folds and fissures of the cerebral cortex, it was Gratiolet who demarcated and named them, and identified 'secondary folds' within each lobe. He was reluctant to ascribe function to the structures he had demarcated:

\footnotetext{
'In a general manner I agree with M. Flourens that the intelligence is one, that the brain is one, that it acts above all as a whole; but this does not exclude the idea that certain faculties of the mind stand in special relation, although not exclusively, with certain cerebral regions' [4].
}

An amusing sideshow took place in a prolonged battle in the Anthropological Society of Paris with Paul Broca on the relations between intelligence and brain size [5].
Much concerned the redoubtable, brilliant Baron Georges Cuvier the 'Aristotle of French biology' who died in 1832. He had a massive head and his unverified brain weight was reported as 1,830 g. Broca eventually concluded:

'In general, the brain is larger in men than in women, in eminent men than in men of mediocre talent, in superior races than in inferior races. Other things equal, there is a remarkable relationship between the development of intelligence and the volume of the brain.'

Gratiolet's studies of comparative anatomy included: Recherches sur l'anatomie de l'hippopotame [Paris, Victor Masson et fils, 1867]. With Francois Leuret (1797-1851), he published his major and remarkable text [6] on comparative cerebral anatomy.

Leuret thought intelligence related to the number of convolutions with their increasing complexity [6] in primates. In England, Franz Joseph Gall [7] had earlier promulgated the idea that:

'different phenomena suppose different apparatus; consequently, the various functions of the brain likewise suppose different organs' [local areas] ...

For example, Gall distinguished six varieties of memory, which he localised in the frontal lobes. Discrete neurological functions and psychological processes were reflected in the surface contours of the skull, a concept that led to the debunked 'art' of phrenology.

Gratiolet, who traced a pathway from the thalamus to the occipital cortex, first described the optic radiations in 1856. But it was Flechsig who, in 1896, first called attention to the sharp turn made by the ventral optic radiation that he called 'temporal knee', or 'temporal loop'.

Gratiolet observed that cranial sutures closed sequentially: sagittal, lambdoid, then coronal. Union occurred earlier in black races. He [1] also deduced that the two sides of the brain controlled movement of the opposite side of the body. He asserted that the frontal convolutions on the left side were in advance of those on the right in their development in the fetus. Hughlings Jackson extended the notion saying, 'if this be so, the left side of the brain is sooner ready for learning. It is the elder brother' [8]. Paul Broca [9] after Marc Dax's unpublished thesis (submitted to Montpellier University in 1836) showed that expressive speech was 'localised' to the third left frontal convolution (the focus of the Broca-Dax controversy). Gratiolet, along with Bouillaud and Trousseau related aphasia to damage to the forebrain and especially the left hemisphere. 
Gratiolet also studied the comparative anatomy of facial expression in his De la physionomie et des mouvements d'expression, published following a notice of his life and work by Louis Grandeau L'expression des émotions chez l'homme et les animaux, 1872.
Gratiolet eventually did relate structure, but not brain size, to function. His lasting and seminal contribution was to show the fixed pattern of the brain's convolutions and to systematize the study of the cortex in man and lower animals.

\section{References}

1 Gratiolet LP: Mémoires sur les plis cerebraux de l'homme et des primates. Paris, Bertrand, $1854, \mathrm{p} 30$.

2 Gratiolet LP: Anatomie comparée du système nerveux. Paris, Baillière, vol 2, 1857, pp 101-124.

3 TH Huxley: Notes on the resemblances and differences in the structure and the development of the brain in man and the apes; in Darwin C: Descent of Man, ed 2. London, Murray, 1874.
4 Head H: Aphasia and Kindred Disorders of Speech. Cambridge, Cambridge University Press, 1926, vol 1, p 16.

5 Gould SJ: The Panda's Thumb. New York, WW Norton, 1980, pp 145-148.

6 Leuret F, Gratiolet LP: Anatomie comparée du système nerveux considéré dans ses rapports avec l'intelligence. Paris, Ballière, vol $1,1839$.
7 Gall FJ: Craniologie ou découvertes nouvelles concernant le cerveau, le crâne et les organes. Paris, Necelle, 1807; Dictionnaire des Sciences Medicales, Paris, 1813, vol 4, p 447.

8 Jackson JH: Notes on the physiology and pathology of language. Med Times Gaz 1886;1: 659-662.

9 Broca PP: Perte de la parole; ramollisement chronique et destruction partielle du lobe antérieur gauche du cerveau. Bull Soc Anthrop Paris 1861;2:235-238. 